Prof. dr.J. W.

Cosman

Mednarodni svet

za izobraževanje

odraslib

\section{IZOBRAŽEVANJE \\ V ZAPORIH}

\section{Pravica do dostojanstva useh članov človeške skupnosti}

$V_{\text {eat }}$

ečina obsojenih kriminalcev v različnih zaporih po svetu je mlajših odraslih. Zvečine so manj izobraženi pa tudi funkcionalno nepismeni. Njihova inteligentnost je podobna inteligentnosti tistih mladih, ki niso v zaporu. Večinoma so se sposobni in voljni učiti ali pa jih je moč navdušiti za učenje.

Kljub temu v nekaterih predelih sveta izobraževalnih programov $v$ zaporih ne poznajo; tam pa, kjer obstajajo, so največkrat maloštevilni in prav nič raznoliki, za nameček pa še dokaj nekakovostni. Med njimi je sicer nekaj redkih izjem, te pa so seveda prej sad osebnih prizadevanj posameznikov in njihove zavezanosti delu kot politike in načrtovanja.

\section{UNESCOVA POSLANICA V BOIU ZOPER IKRIMINAL}

Kriminal pogosto nepopravljivo prizadene kriminalčevo življenje, po drugi strani pa ško-

Vsakršna prevencija Združenih narodov št. 46/152 dne 18. decembra 1991 zapisali tole:

kriminala je neposreden prispevek $k$ vzdrževanju miru in varnosti di družbi. Tako so v resoluciji
"... današnji svet je še zmeraj svet nasilja in drugih oblik večjih kaznivih dejanj. Ta pojav, naj se zgodi kjerkoli, ogrozi veljavo zakonov. «
»Prepričani smo, da povečevanje obsega kriminalnih dejanj zavira razvoj in splošno blaginjo človeštva, prav tako pa povzroči splošen nemir v družbi. Če bo kriminal še naraščal, bosta napredek in razvoj žrtvi kriminala.«

»Prav tako ugotavljamo, da sta demokracija in boljše življenje zares mogoča le v svetu miru in varnosti za vse. Kriminal ogroža stabilnost in varnost okolja. Prevencija kriminala in pravičnost na tem področju ob upoš- tevanju človekovih pravic sta tako neposreden prispevek $\mathrm{k}$ vzdrževanju miru in varnosti.«

Poleg izboljšanja gospodarskih, družbenih in kulturnih razmer, ki so večinoma vzrok za povečevanje obsega kriminalnih dejanj, je eden najboljših načinov za preobrazbo zapornikov priložnost za nadaljnje izobraževanje. $Z$ »nadaljnjim izobraževanjem « mislimo na "celoto organiziranih izobraževalnih procesov, ne glede na vsebino, stopnjo in uporabljene metode, bodisi da je to izobraževanje formalno ali kakšno drugo. Lahko je nadaljevanje ali nadomestek začetnega izobraževanja v šolah, srednjih šolah ali na univerzi, pa tudi vajenskega izobraževanja, s čmer te osebe, $\mathrm{ki}$ jih družba obravnava kot odrasle, razvijejo svoje sposobnosti, obogatijo znanje, izboljšajo strokovno in poklicno usposobljenost. Lahko pa se takšno izobraževanje pokaže tudi v spremembi njihovih stališč in obnašanja. Prizadeva si za njihov popoln osebnostni razvoj in za možnost njihovega sodelovanja $\mathrm{v}$ uravnovešenem in neodvisnem družbenem, ekonomskem in kulturnem razvoju.« (UNESCO 1976)

Izobraževanje v zaporih je, nasplošno gledano, večinoma obrobna dejavnost, pogosto nepomembna in $v$ glavnem neučinkovita. Vzroke za to je iskati pri mnogih uradnih osebah, $\mathrm{v}$ upravi zaporov, še bolj pa v odnosu javnosti in vlade do kriminala, kriminalcev in do obsojanja kriminala in kriminalcev.

\section{TRADICIONALNA PRAKSA UPRAVLJANIA ZAPOROV}

Upravljanje zaporov zdaj sloni na povezavi discipline in nadzora, osamitve, delovnega usposabljanja in posebne obravnave. 
$V$ današnjih zaporih večinoma nadzorujejo vse vidike posameznikovega življenja. Nad zaporniki imajo malodane popolno moč, pri čemer uveljavljajo lastne mehanizme represije in kaznovanja. Zapornike skušajo preobraziti z uveljavljanjem svoje volje, z zatiranjem ali vsiljevanjem novih načinov razmišljanja, čutenja in delovanja.

$\mathrm{V}$ zaporih se poslužujejo osamitve zapornikov. Preprečujejo, da bi se povezali z zunanjim svetom pa tudi z drugimi zaporniki. Samoto uporabljajo kot sredstvo za podrejanje zapornikov in kot način preobrazbe, včasih tudi za to, da zapornike navadijo na predpisana pravila obnašanja, drugič spet za to, da zbudijo njihovo vest, najpogosteje pa gre za prisilno uničenje zapornikovih odnosov $\mathrm{z}$ drugimi, izvzemši tiste odnose, ki jih zapor predpisuje.

Zapori, kakršne poznamo danes, prav tako poskušajo doseči, da zaporniki pridobijo nekatere spretnosti in delovne navade, da postanejo redoljubni in ubogljivi, vse $\mathrm{z}$ namenom, da bi jih pripravili na kasnejšo zaposlitev. Takšen, povsem utilitaristični cilj je tudi opredelil naravo usposabljanja in izobraževanja zapornikov.

Nenazadnje uporabljajo zapori metodo obravnave, ki jo včasih imenujejo popravno usposabljanje. Večina programov obravnave zapornikov pri tem sloni na predvidevanju, da je kriminalno obnašanje mogoče razložiti kot psihopatološko, takšno, ki zahteva zdravljenje in najrazličnejše oblike terapije.

O tem, koliko je kateri od teh načinov preobrazbe zapornikov učinkovit ali koliko so učinkoviti nekateri drugi najpogostejši poskusi izobraževanja v zaporih, bi lahko povedali bolj malo dokončnega. Najpogosteje gre za povezovanje zaporniške tehnologije s prevladujočo vzgojno-popravno ideologijo.

$\mathrm{Na}$ splošno pa izobraževalne razmere, kakršne ponujajo zapori, ne odsevajo osnovnega namena izobraževanja, t. j. razvoja človeka, kot ga predvideva načelo človekovega dostojanstva v Svetovni deklaraciji o človekovih pravicah (člen 26) in v Mednarodni konvenciji o ekonomskih, družbenih in kulturnih pravicah (člen 13): "... izobraževanje naj stremi k polnemu razvoju ... človekove osebnosti ...

\section{PRAVICA DO IZOBRAŽEVANIA}

Združeni narodi so, v letih, odkar obstajajo, sprejeli mnogo odličnih standardov in norm na področju preprečevanja kriminala in kriminalnega prava. Med drugim se nanašajo na pravico do izobraževanja, npr. v Resoluciji generalne skupščine 45/111, sprejeti dne 14 . decembra $1990 \mathrm{z}$ naslovom »Osnovna načela za obravnavo zapornikov « (Združeni narodi 1992, str. 110):

»1. Vsi zaporniki naj bodo deležni obravnave ob spoštovanju njihovega dostojanstva in priznavanju njihove človeške vrednosti.«

$» 6$. Vsi zaporniki naj se imajo pravico udeleževati kulturnih dejavnosti in izobraževanja za poln razvoj njihove človeške osebnosti. «

Velika ovira na poti k uresničitvi možnosti za izobraževanje $\mathrm{v}$ zaporih pa je to, da namen in načelo kazenskega prava nista v skladu z izobraževanjem. Večinsko javno mnenje se $s$ tem strinja, kar se zrcali tudi v vladnih zakonih in politiki kaznovanja. Namen kriminalnega prava je namreč kaznova-
Osnovni namen izobraževanja je razvoj osebnosti. nje. Po tradiciji je kazensko pravo zmeraj kaznovalno, kar kažejo že nekateri ljudski izrazi, kot so »zadostiti pravici«, »biti si bot « in »odmeriti primerno kazen«. Zakonsko kaznovanje je dejansko nekaj, kar ustreza maščevanju, pa naj bodo njegovi postopki še tako določeni.

\section{KAZNOVANJE NASPROTI IZOBRAŽEVANJU}

Kaznovanje je tedaj nekaj, kar pride nad človeka, je trpljenje, ki povzroči sovraštvo in nasilje; nasprotno pa je izobraževanje podlaga rasti in razvoja človeka in njegove osebnosti, in to $v$ vseh razsežnostih. Še posebej gre pri tem za njegove intelektualne in moralne sposobnosti. Kaznovanje in izobraževanje nista $v$ skladu. Še več, nasprotujeta si! Tako ima izobraževanje, ki si prizadeva za razvoj človeka, bolj malo možnosti za uspeh v svetu kazenskega prava, katerega namen in načelo je predvsem kaznovanje. In tako se zgodi, da ni izobraževanje $\mathrm{v}$ zaporih nič več kot usposabljanje za »osnovne življenjske in delovne veščine" in je navadno omejeno na povsem osnovno raven. Sicer pa so to izobraževalne
AS B. 


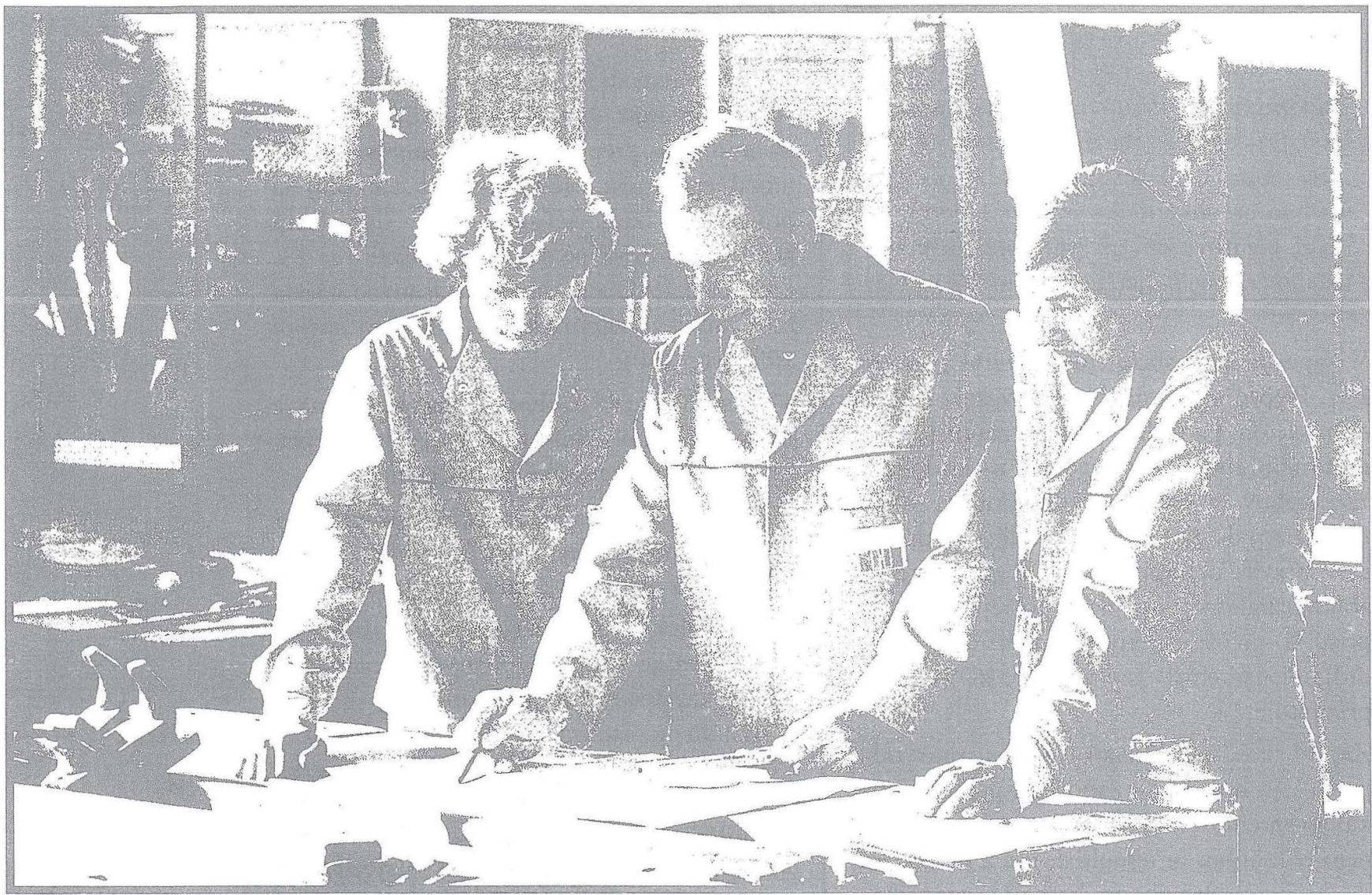

dejavnosti, s katerimi nihče niti ne poskuša doseči "polnega razvoja človekove osebnosti«。

\section{NASILJE LAHKO RODI LE NASILJE}

V primitivnih družbah je bila uporaba nasilja neznanski problem. Če ga niso nadzorovali, je to kaj kmalu pripeljalo do neskončne verige nasilnih dejanj in do razpada skupnosti. Čeprav se nasilje pričenja pri človeku, so ga v teh skupnostih obravnavali kot naravno silo, hujšo od viharjev, gozdnih požarov in kuge, kot silo, ki ogroža preživetje družbe, in potemtakem kot sveto silo. (R . Girard 1977.)

V tistih davnih časih je človek skušal takšne zastrašujoče sile nadzorovati s tabuji in obredi. Ob nasilju in potrebi po maščevanju se je celo v same obrede naselilo nasilje, ki je napovedovalo, da bo prišlo do še večjega povratnega nasilja v obliki žrtvenih obredov, ti pa naj bi preprečili grozeči družbeni propad.

V nam bližjih časih so obredna žrtvovanja kot način nadzora nad maščevanjem ljudi nadomestili sodni sistemi. Vsi načini maščevanja so se zbrali v rokah sodstva. Tako kot obredna žrtvovanja so tudi sodni sistemi v za- četku spadali v območje svetega in temeljili na avtoriteti in teologiji. To tudi pojasnjuje skrivnostno, transcendentalno lastnost, ki jo ti sistemi še zmeraj kažejo, četudi so njihove teološke osnove šle v pozabo.

Danes so sodni sistemi nekaj verodostojnosti izgubili, še posebej v kulturah, v katerih reli-

Družba se v neskončnost pogovarja o pravici do kaznovanja, o pretanjeno določenih stopnjah kaznovanja, o koristih kaznovanja, o razmerjih med kaznijo in zagrešeno škodo ali krivdo, o vsem tem, česar ni mogoče dokončno uskladiti. Dejstvo pa je, da ni še nihče uspešno utemelil kaznovanja druge osebe kot nekaj dobrega in kot nekaj, kar vodi v blaginjo. Kaznovanje, naj bo še tako pravno utemeljeno, piše L. Morin $(1981), » n i$ boljše od samega zla $k$, in opozarja, da tisti, ki se mu preda, sokuži druge in sebe, pri čemer se počuti ponizanega in poniža druge $«$. M. Foucault pa piše $(1979$, str. 48$)$, da studi pri izvajanju najmilejše oblike kazni, četudi so še tako natančno upoštevane pravno določene oblike, še zmeraj vlada maščevanje 
gija izginja in transcendentalna podoba zakona bledi, v katerih postaja zakon človeški izdelek, takšen, ki se ne nanaša na nekaj dejanskega ali naravnega.

In vendar je družba zgrožena nad pomenom kazenskih določb. Te določbe družbe ne varujejo pred kriminalom, niti ne škodijo (razen povsem obrobno) (Schumann in drugi 1987) niti ne koristijo kateremu koli pomembnemu namenu, ki naj bi ga imele. Namenjene so zgolj potešitvi jeze in zadovoljevanju želje po

Kaznovanje ne vodi v prevzgojo, pomiritev ali mir.

maščevanju, in sicer tako, da človeka, ki je zagrešil kaznivo dejanje, izpostavijo trpljenju.

Iz moralnega razmišljanja le stežka izločimo pojma nagrada ali kaznovanje, kar kaže, kako ustaljene so poti človekovega mišljenja in čustev. Dejstvo, da je tako, pa še ne opravičuje tega, da se nič ne spremeni. Pa vendar so se posamezne družbe s sodnimi sistemi zmeraj znova odzivale na primarne vzgibe jeze in maščevanja. Zdi se, da se do danes na tem področju ni prav nič spremenilo.

Konec devetnajstega stoletja in v velikem delu dvajsetega stoletja se je pomen različnih utemeljitev kaznovanja zmanjšal, saj sta popustljivost do maščevalne strasti in utilitarni cilj preprečevanja kriminala prodrla $v$ večino teoretičnih razmišljanj o kaznovanju. Tedaj je zavladalo prepričanje, da je kriminal moč preprečiti tako, da prestopnike ustrahujemo pred nadaljnjimi kriminalnimi dejanji. Morda tudi tako, da odvrnemo od kriminala tiste, ki bi utegnili zagrešiti zločin, in sicer s tem, da preprečimo okoliščine, $v$ katerih bi do zločina lahko prišlo, ali morda tako, da kriminalce rehabilitiramo. Do sedemdesetih let se je nabralo precej pričevanj in dokazov o neuspešnosti teh teorij in njihovem zanemarljivem učinku v praksi. Od sedemdesetih let dalje so kaznovalne teorije znova pridobile nekaj verodostojnosti. Tedaj se je uveljavilo prepričanje, da je tudi opravičevanje kaznovanja samo zase zločin, ki zasluži kazen, da je kaznovanje samo po sebi cilj, da je dobro in da bi moralo » biti sorazmerno « s škodljivostjo prekrška in s tem, koliko graje si zasluži prestopnik.

Zdi se, da je za v neki drug namen potrebno oblikovati še eno osnovno načelo, načelo, ki bo dlje od tega, kar dopušča zakon, ki bo dlje od pravic, dlje od sodnih sistemov, dlje od pravice same, ki bo doseglo višjo raven »inherentnega dostojanstva in vrednote vseh članov človeške skupnosti «.

\section{SKLEPNA MISEL}

V zvezi s kazenskim pravom razmišljamo o njegovi moči, da nagradi ali kaznuje. Takšno kazensko pravo pa je, in bo, nepremagljiva ovira za izobraževanje odraslih v zaporih. Obstajajo namreč nasprotujoči si pogledi na cilj kazenskega prava. Spoznali smo, da potrebujemo novo in celostno opredelitev tega cilja, ki naj bi pomagala razjasniti podrobnosti izvajanja izobraževalnih proInstitut kazenskega
prava ovira
izobraževanje v
zaporih. gramov, tako z zakonskega kot drugih vidikov. S tem v zvezi potrebujemo izjavo, ki bi odsevala načelo Združenih narodov »o inherentnem dostojanstvu in vrednotah vseh članov človeške skupnosti . Izjava bi bila podlaga za možnost izobraževanja $v$ zaporih in bi tudi koristila razvoju politike obsojanja in kazenskega prava nasploh. Takšna izjava bi sčasoma vplivala na zakone in politiko držav.

\section{LITERATURA}

Foucault, M. (1979): Discipline and Punishment (A. Sheridian, Trans.). New York, Vintage Books.

Girard. R. (1979): Violence and the Sacred (P. Gregory, Trans.). Baltimore, The Johns Hopkins University Press.

Morin, L. (1981): "Correctional education as Practice of the Judicial Approach: A Contradiction «. V. L. Morin (ur.), On prison Education, Ottawa, Canadian Government Publishing Centre.

Schumann, Karl F., Berlitz, Claus, Guth, Hans W. in Kauilitzki, Rainer (1987): Jugendkriminälitat and die Grenzen der Generalprävention. Cologne, Luchterhand.

UNESCO (1976), »Recommendation on the Development of Adult Education, " adopted 26 November 1976 at the 19th Session of the General Conference of UNESCO, held in Nairobi, Paris: UNESCO.

United Nations (1992). Compendium of United Nations Standards and Norms in Crime Prevention and Criminal Justice, New York: United Nations. 